\title{
Defective Stimulation of Adipocyte Adenylate Cyclase, Blunted Lipolysis, and Obesity in Pseudohypoparathyroidism 1a
}

\author{
JOHANNA M. KAARTINEN, MARJA-LIISA KÄÄR, AND JORMA J. OHISALO \\ Department of Medical Chemistry. University of Helsinki, Helsinki JJ.M.K., J.J.O.J, and Departme'nt of \\ Pediatrics, Oulu University' Central Hospital, Oulu [11-L.K.J, Finland
}

\begin{abstract}
Adipocyte plasma membranes were isolated from four patients with type 1a pseudohypoparathyroidism, a disease in which deficiency of the stimulatory guanine nucleotide binding protein $G_{s}$ has been reported, and from controls. Stimulation of adenylate cyclase by isoproterenol was defective, whereas inhibition of forskolin-stimulated cyclase activity by $\mathbf{N}^{6}$-(phenylisopropyl)adenosine was normal. The patients had low serum FFA concentrations and developed obesity in childhood. These results suggest that pseudohypoparathyroidism $\mathrm{Ia}$ is connected with a blunted stimulatory response of adenylate cyclase, possibly because of low $G_{s}$ activity, and that this blunted response may lead to decreased lipolysis and to obesity. (Pediatr Res 35: 594-597, 1994)
\end{abstract}

\section{Abbreviations}

$G_{i}$, inhibitory guanine nucleotide binding protein $G_{s}$, stimulatory guanine nucleotide binding protein PHPT, pseudohypoparathyroidism

Adoption and twin studies $(1,2)$ have suggested that obesity is inherited genetically and not only socially. Furthermore, it is known that although losing weight by dieting is easy, returning to the previous higher weight thereafter is almost inevitable. This suggests that there are molecular mechanisms leading to and maintaining obesity. Defective stimulation of lipolysis could be a mechanism causing or maintaining an increased adipose tissue mass. In fact, there is evidence that stimulation of lipolysis is defective in obesity both in human subjects (3-5) and in experimental animals $(6,7)$. Lipolysis is controlled by intracellular cAMP, whose concentrations in the fat cell are increased by hormone receptors, stimulating adenylate cyclase via the stimulatory guanine nucleotide binding protein, $G_{s}(8) . G_{s}$ is present in concentrations that are orders of magnitude higher than the receptors. A decreased amount of $\beta$-adrenergic receptors (5) or $\mathrm{G}_{\mathrm{s}}(9,10)$ in adipocyte plasma membranes or their altered functional status (7) could be an explanation for the development and maintenance of obesity. A decreased amount of $G_{s}$ has, in fact, been reported in obesity $(9,10)$.

PHPT type la is a syndrome characterized by the clinical picture of hypoparathyroidism but elevated circulating parathormone levels, short stature, obesity, congenital hypothyroidism, Albright's hereditary osteodystrophy, brachydactyly, and mild mental retardation (11). In this dominantly inherited disease, the

Received July 15, 1993; accepted December 2, 1993.

Correspondence: Jorma J. Ohisalo, M.D., Department of Medical Chemistry, University of Helsinki, Siltavuorenpenger 10a, $00170 \mathrm{Helsinki,} \mathrm{Finland.}$

Supported by The Sigrid Juselius Foundation and The Academy of Finland. transmembrane signaling system is defective, and the amount of $\mathrm{G}_{\mathrm{s}}(\boldsymbol{x}$-protein has been reported to be decreased by approximately $50 \%$ (12-14). A mutation of the start codon of protein synthesis and a concomitantly untranslated or mistranslated mRNA has been described (15).

Here we report investigations on fat metabolism in adipose tissue in PHPT type $1 \mathrm{a}$ in which a $G_{\mathrm{s}}$ deficiency has been reported.

\section{MATERIALS AND METHODS}

Patients. All the pseudohypoparathyroid patients described here had brachydactyly as well as other features of Albright's hereditary osteodystrophy and somewhat but not grossly retarded mental development. They all had elevated serum parathormone levels even when made normocalcemic with dihydrotachysterol, indicating parathormone resistance, and elevated TSH values before thyroid hormone replacement (Table 1). It is therefore clear that all the patients had PHPT type la, which has been shown to be connected with low plasma membrane $G_{s}$ activity. Patients 1, 2, and 3 were siblings; their pedigree is shown in Figure 1. Their mother has osteodystrophy but has normal TSH, PTH, and calcium values. Patient 6 is the mother of patient 5; she also has a newborn daughter who has the disease and an obviously healthy son. All the patients were normocalcemic and euthyroid at the time when fat biopsies and samples for plasma FFA determinations were taken. All four patients whose adipocyte membranes were studied were obese. The exact determination of the degree of obesity is difficult because the body mass index is not useful with children and because the patients are of very short stature and stocky build. The body weights of patients 1-8 were compared with age-, sex-, and height-matched Finnish national statistics. This comparison gave an average overweight of $50 \pm 13 \%($ mean \pm SEM $)$

Table 1. Characteristics of the patients*

\begin{tabular}{crlcc}
\hline Patient & Age & Sex & $\begin{array}{c}\text { PTH (ng/L) } \\
\text { (NR 10-55) }\end{array}$ & $\begin{array}{c}\text { TSH (mU/L) } \\
\text { (NR 0.3-4) }\end{array}$ \\
\hline 1 & 15 & F & 307 & 11.6 \\
2 & 12 & M & 352 & 16.1 \\
3 & 6 & M & 336 & 11.0 \\
4 & 13 & F & 134 & 14.1 \\
5 & 2 & M & 466 & 8.9 \\
6 & 30 & F & 427 & 8.2 \\
7 & 28 & F & 95 & 7.0 \\
8 & 3 & M & 115 & 33.6 \\
\hline
\end{tabular}

* The PTH determinations were done at a time when the patients were normocalcemic (with or without dihydrotachysterol). and TSH values were determined earlier when the patients had not been receiving thyroid hormone replacement. NR, normal range. 


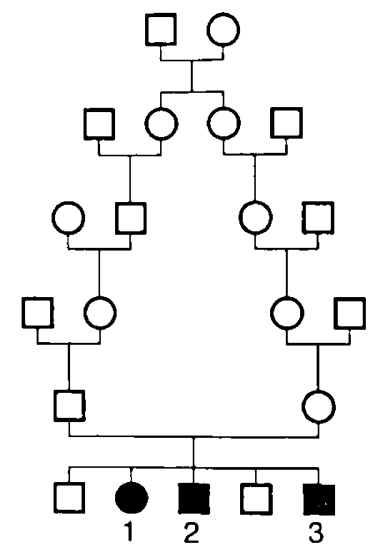

Fig. 1. The family tree of patients 1,2 , and 3 .

It was not possible to obtain fat samples from age- and weightmatched controls because the patients were children. The control material used therefore was from adults. The exact characteristics will be given in the Results section, and the justification for using adult controls will be discussed below.

Isolation of cell membranes. Subcutaneous adipose tissue samples were excised from the middle abdominal region from a small incision with the subjects under local anesthesia (without adrenaline) or under general anesthesia at the beginning of routine operations such as cholecystectomies and hysterectomies. Fat cells were isolated from these samples by a modification of the method of Rodbell (16) in the presence of collagenase $(0.5 \mathrm{mg} /$ $\mathrm{mL}$ ) with constant shaking at $2 \mathrm{~Hz}$ at $37^{\circ} \mathrm{C}$ in a buffer containing $125 \mathrm{mM} \mathrm{NaCl}, 5 \mathrm{mM} \mathrm{KCl}, 1 \mathrm{mM} \mathrm{CaCl}, 2.5 \mathrm{mM} \mathrm{MgCl}_{2}, 1 \mathrm{mM}$ $\mathrm{KH}_{2} \mathrm{PO}_{4}, 4 \mathrm{mM}$ glucose, $2 \% \mathrm{BSA}$, and $25 \mathrm{mM}$ Tris at $\mathrm{pH} 7.4$. After $60 \mathrm{~min}$, the cells were filtered through a nylon cloth and washed three times with the same buffer without collagenase. The cells were homogenized in 10 volumes of buffer containing $150 \mathrm{mM} \mathrm{NaCl}, 1 \mathrm{mM}$ EDTA, $10 \mathrm{mM}$ Tris at $\mathrm{pH} 7.4,1 \mu \mathrm{M}$ leupeptin, and $4 \mu \mathrm{M}$ phenylmethylsulfonyl fluoride using a Potter-Elvehjem glass-Teflon homogenizer. The homogenate was centrifuged at $10000 \times g$ for $20 \mathrm{~min}$ and the pellet was resuspended in the homogenization buffer.

Adenylate cyclase assay. Adenylate cyclase activity of fresh adipocyte plasma membranes was assayed in a total volume of $500 \mu \mathrm{L}$ in the presence of $150 \mathrm{mM} \mathrm{NaCl}, 10 \mathrm{mM} \mathrm{KCl}, 10 \mathrm{mM}$ $\mathrm{MgCl}_{2}, 1 \mathrm{mM}$ EDTA, $2 \mathrm{mM}$ DTT, $1 \mathrm{mM}$ ATP, $100 \mu \mathrm{M}$ papaverine, $1 \mathrm{mM}$ guanosine triphosphate, BSA $(1 \mathrm{mg} / \mathrm{mL}), 50$ $\mathrm{mM}$ Tris- $\mathrm{HCl}, \mathrm{pH} 7.5$, and adenosine deaminase $(1 \mu \mathrm{g} / \mathrm{mL}) .7$. Deacetyl-6-(N-acetylglycyl)forskolin $(20 \mu \mathrm{M})$ and different concentrations of $\mathrm{N}^{6}$-(phenylisopropyl)adenosine or isoproterenol were added as indicated. After $20 \mathrm{~min}$ at $37^{\circ} \mathrm{C}$, the incubations were terminated by boiling the tubes for $2 \mathrm{~min}$. The boiled samples were then centrifuged and the supernatants were assayed for cAMP using a kit from Advanced Magnetics (Cambridge, MA).

$F F A$. Samples for serum FFA determinations were taken the morning after an overnight fast. The assay was done by using the NEFA C-kit (Wako Chemicals GmbH, Neuss, Germany) and oleic acid as the standard.

Reagents. Adenosine deaminase (type VIII from calf intestine), $\mathrm{N}^{6}$-(phenylisopropyl)adenosine, fatty acid-free BSA, isoproterenol. $\mathrm{HCl}$, and collagenase were purchased from Sigma Chemical Co. (St. Louis, MO). 7-Deacetyl-6-(N-acetylglycyl)forskolin was from Calbiochem (San Diego, CA), and the cAMP assay kit (catalog no. 6301) from Advanced Magnetics.

Ethical considerations. The study was approved by the ethical commissions of the 3rd Department of Medicine and 2nd Department of Surgery of Helsinki University Central Hospital.
RESULTS

The adenylate cyclase assay was linear with respect to protein concentration up to $70 \mu \mathrm{g}$ per assay, corresponding to approximately $200 \mu \mathrm{L}$ of fat cells. When we studied the PHPT patients, we used plasma membranes derived from $12-16 \mu \mathrm{L}$ of cells per assay tube. The small size of the samples from PHPT patients prevented reliable protein assay, but the harmonic means of forskolin-stimulated cyclase activities were 26 and $39 \mathrm{pmol} / \mathrm{min} /$ $\mu \mathrm{L}$ fat cells in the control and PHPT groups, respectively. However, there was much interindividual variation in both groups. Our experience is that this is caused by variation in the yield in plasma membrane isolation.

The dose-response curve of adipocyte plasma membrane adenylate cyclase to isoproterenol of patients 1-4 compared with 12 controls is displayed in Figure 2. The body mass indices of the controls were $32.1 \pm 1.7$ and ages $51.6 \pm 4.8$ y (means \pm SEM). The adenylate cyclase activities are shown on a scale of 0 to $100 \%$, measured in the presence of 7-deacetyl-6-( $\mathrm{N}$-acetylglycyl)forskolin, which stimulates the cyclase directly. It is evident that the basal unstimulated activities were similar but the membranes prepared from the type la pseudohypoparathyroid patients had decreased responsiveness to isoproterenol. The difference was statistically significant at $p=0.041$ (repeated measures analysis of variance).

The inhibitory arm of cyclase regulation by $\mathrm{N}^{6}$-(phenylisopropyl)adenosine, an adenosine Al receptor agonist, was studied in the presence of exogenous adenosine deaminase to remove endogenous adenosine. The samples from pseudohypoparathyroid patients were the same as described above; the control material came from six subjects whose ages were $52.7 \pm 4.5 \mathrm{y}$ and body mass indices $26.5 \pm 1.9 \mathrm{~kg} / \mathrm{m}^{2}$ (means $\pm S E M$ ). Inhibition of $7-$ deacetyl-6-(N-acetylglycyl)forskolin-stimulated adenylate cyclase by $\mathrm{N}^{6}$-(phenylisopropyl)adenosine was similar in both groups (Fig. 3).

Fasting serum FFA of patients $1-5$ (relative body weight, 144 $\pm 17 \%$; means \pm SEM) were measured and compared with five age-matched control subjects (relative body weight, $124 \pm 10 \%$ ) selected from hospital records of 200 FFA determinations. All the control subjects were found healthy at the time of investigation. Four of the control subjects had an advanced bone age compared with calendar age, as was also the case with the

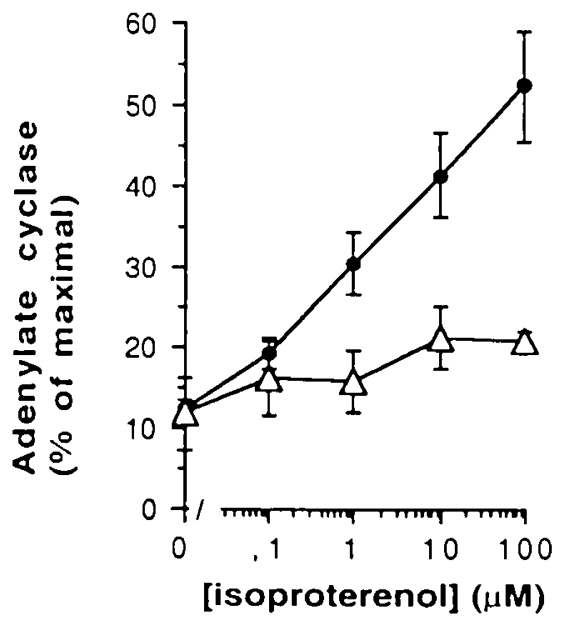

Fig. 2. Effect of isoproterenol on adenylate cyclase activity of fat cell plasma membranes prepared from patients $1-4$ and controls. Fat cell plasma membranes were prepared as described in the text. The membranes were incubated with different concentrations of isoproterenol and the cAMP formed was measured by RIA. Cyclase activity is expressed on a scale from zero activity to $100 \%$ measured in the presence of 20 $\mu \mathrm{M}$ 7-deacetyl-6-(N-acetylglycyl)forskolin. I'ertical hars indicate SEM. $\triangle$. pseudohypoparathyroid: $\bullet$ controls. 


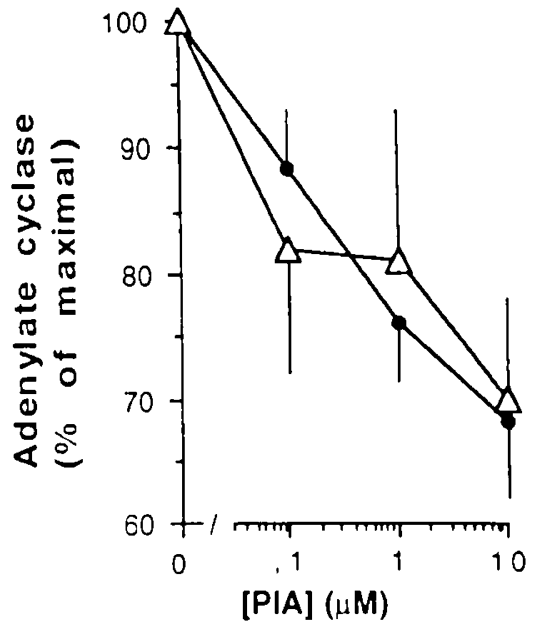

Fig. 3. Inhibition of adipocyte plasma membrane adenylate cyclase by $\mathrm{N}^{6}$-(phenylisopropyl)adenosine $(P I A)$ in pseudohypoprathyroid and control subjects. Plasma membranes were isolated as described in the text. Adenylate cyclase was stimulated by $20 \mu \mathrm{M}$ 7-deacetyl-6-(N-acetylglycyl)forskolin in the presence of adenosine deaminase, and different concentrations of $\mathrm{N}^{6}$-(phenylisopropyl)adenosine were added. Cyclase activity is expressed on a scale from zero activity to $100 \%$ measured in the presence of $20 \mu \mathrm{M}$ 7-deacetyl-6-(N-acetyl-glycyl)forskolin. l'ertical bars indicate SEM. $\triangle$, pseudohypoparathyroid; $\bullet$, controls.

Table 2. Serum FFA concentrations in pseudohypoparathyroid and control subjects*

\begin{tabular}{lcc}
\hline & $\begin{array}{c}\text { Serum FFA } \\
(\mu \mathrm{mol} / \mathrm{L})\end{array}$ & Age $(\mathrm{y})$ \\
\hline Control & $735 \pm 198$ & $10.8 \pm 1.3$ \\
Pseudohypoparathyroid & $190 \pm 54$ & $9.6 \pm 2.4$ \\
\hline
\end{tabular}

* The values are mean \pm SEM of five subjects.

pseudohypoparathyroid patients. One of the control subjects had hypoglycemia in the past. Two of the control subjects were obese. Serum FFA were low in the pseudohypoparathyroid patients compared with controls (Table 2); the difference was statistically significant at $p=0.029$. The mean value in the pseudohypoparathyroid patients is below the normal range of $0.3-1.0 \mathrm{mmol} / \mathrm{L}$ given by the manufacturer of the assay kit.

\section{DISCUSSION}

The present results suggest that the stimulation of adenylate cyclase via the $\beta$-adrenergic receptor and $\mathrm{G}_{\mathrm{s}}$ is defective in fat cells in PHPT type 1a. The finding of low serum FFA concentrations in the patients is in accordance with this; in obese individuals, FFA concentrations are usually elevated (17). Control samples for studies of cyclase regulation could not be obtained from age-matched material. However, there is a lot of evidence suggesting that adult controls could be used. Most importantly, direct measurements have shown that the stimulatory arm of cyclase regulation is similar in infants and adults $(18,19)$. Secondly, small fat cells are more sensitive to stimulation by isoproterenol than large cells (Kaartinen $e t$ al., unpublished manuscript); because cells are smaller in childhood, if anything the cells of children would be expected to be more and not less sensitive. Furthermore, the responses of the older two patients who already had reached puberty were similar to those of the smaller children. Finally, the inhibitory responses were similar in the patients and controls. It is also possible, of course, that there are differences in adenylate cyclase per se.

The finding of low FFA concentration in PHPT is in contrast with the report of Carlson et al. (20). A closer look at the data of Carlson ot al., however, shows that their patient material consisted of only two type la and four type $1 \mathrm{~b}$ patients who do not have a G-protein defect. The isoproterenol-stimulated FFA concentrations, in fact, were lower in pseudohypoparathyroid patients than in controls and the SEM values shown at 15 min do not overlap. Other reasons for their different conclusion are that their samples were stored for long periods and their basal FFA levels were well above the upper limit of normal values.

$\mathrm{G}_{\mathrm{i}}$-mediated events in platelets have been reported to be nor$\mathrm{mal}$ in PHPT (21). The inhibition of adipocyte adenylate cyclase via the adenosine $A 1$ receptor was normal in our patients, which is in contrast with what is usually found in obesity $(4,22)$. This could be caused by an effect of $\mathrm{G}_{\mathrm{i}}$ on $\mathrm{G}_{\mathrm{s}}$ through common $\beta \gamma$ subunits by the law of mass action.

We conclude that adipocyte plasma membranes isolated from patients with PHPT type la had defective stimulatory responses to $\beta$-adrenergic stimulation but normal inhibitory response to an adenosine analog. The patients had low serum FFA concentrations and developed obesity early in life.

Acknowledgment. The authors thank Iina Kajanoja for expert technical assistance.

\section{REFERENCES}

1. Stunkard AJ, Sørensen TIA. Hanis C, Teasdale TW, Chakraborty R, Schull WJ. Schulsinger F 1986 An adoption study of human obesity. N Engl J Med 314:193-198

2. Stunkard AJ, Foch TT, Hrubek Z 1986 A twin study of human obesity. JAMA 256:51-54

3. Connacher AA. Bennet WM. Jung RT, Bier DM. Smith CCT, Scrimgeour CM. Rennic MJ 1991 Effect of adrenaline infusion on fatty acid and glucose turnover in lean and obese human subjects in the post-absorptive and fed states. Clin Sci 81:635-644

4. Coon P, Greenberg AS, Goldberg AP, Londos C 1991 Regional and obesitylinked differences in adenylyl cyclase-linked receptor signalling in human adipocytes. J Cell Biochem Suppl 15B:23(abstr)

5. Martin LF, Klim CM, Vannucci SJ, Dixon LB, Landis JR. LaNoue KF 1990 Alterations in adipocyte adenylate cyclase activity in morbidly obese and formerly morbidly obese humans. Surgery 108:228-235

6. Muzzin P, Revelli J-P, Kuhne F, Gocayne JD. McCombic WR, Venter JG, Giacobino J-P. Frazer CM 1991 An adipose tissue-specific $\beta$-adrenergic receptor. Molecular cloning and down-regulation in obesity. J Biol Chem 266:24053-24058

7. Naim M, Katz Y, Brand JG, Kare MR 1990 Nonreceptor-mediated responses of adenylate cyclase in membranes from liver. muscle and white and brown adipose tissue of obese ( $\mathrm{fa} / \mathrm{fa}$ ) and lean (Fa/) Zucker rats. Proc Soc Exp Biol Med 195:369-374

8. Gilman AG 1987 G-proteins: transducers of receptor-generated signals. Annu Rev Biochem 56:615-649

9. Ohisalo JJ, Milligan G 1989 Guanine nucleotide binding proteins $G_{i}$ and $G_{s}$ in adipocyte plasma membranes of normal, hypothyroid and obese human subjects. Biochem J 260:843-847

10. Begin-Heick $N 1990$ Quantification of the $\alpha$ and $\beta$ subunits of the transducing elements $\left(\mathrm{G}_{\mathrm{s}}\right.$ and $\left.\mathrm{G}_{\mathrm{i}}\right)$ of adenylate cyclase in adipocyte membranes from lean and obese $(o h / o b)$ mice. Biochem J 268:83-89

11. Levine MA, Aurbach GD 1989 Pseudohypoparathyroidism. In: DeGroot LJ, Besser GM, Cahill Jr GF, Marshall JC, Nelson DH, Odell WD, Potts Jr JT, Rubenstein AH, Steinberger E (eds) Endocrinology, 2nd Ed. WB Saunders, Philadelphia, pp 1065-1079

12. Levine MA, Downs Jr RW, Moses A, Breslau NA, Marx SJ, Lasker RD, Rizzoli RE, Aurbach GD, Spiegel A 1983 Resistance to multiple hormones in patients with pseudohypoparathyroidism. Association with deficient activity of guanine nucleotide regulatory protein. Am J Med 74:545-556

13. Levine MA, Ahn TG, Klupt SF, Kaufman KD, Smallwood PM, Bourne H, Sullivan KA, Van Dop C 1988 Genetic deficiency of the a subunit of the guanine nucleotide binding protein $G_{s}$ as the molecular basis for Albright hereditary osteodystrophy. Proc Natl Acad Sci USA 85:617-625

14. Patten JL, Levine MA 1990 Immunochemical analysis of the $\alpha$-subunit of the stimulatory G-protein of adenylyl cyclase in patients with Albright's hereditary osteodystrophy. J Clin Endocrinol Metab 71:1208-1214

15. Patten JL. Johns DR, Valle D, Eil C, Gruppuso PA, Stecle G, Smallwood PM, Levine MA 1990 Mutation in the gene encoding the stimulatory G-protein of adenylate cyclase in Albright's hereditary osteodystrophy. N Engl J Med 322:1412-1419

16. Rodbell M 1964 Metabolism of isolated fat cells. J Biol Chem 239:375-380 
17. Robertson DA, Singh BM, Nattrass M 1991 Effect of obesity on circulating intermediary metabolite concentrations in the absence of impaired glucose tolerance. Int J Obesity 15:635-645

18. Marcus C, Sonnenfeld T. Karpe B, Bolme P, Arner P 1989 Inhibition of lipolysis by agents acting via adenylate cyclase in fat cells from infants and adults. Pediatr Res 26:255-259

19. Marcus C, Ehren H, Bolme P. Arner P 1988 Regulation of lipolysis during the neonatal period. Importance of thyrotropin. J Clin Invest 82:1793-1797

20. Carlson HE, Brickman AS, Burns TW, Langley PE 1985 Normal free fatty acid response to isoproterenol in pseudohypoparathyroidism. J Clin Endocrinol Metab 61:382-384

21. Motulsky HJ, Hughes RJ, Brickman AS, Farfel Z, Bourne HR, InseI PA 1982 Platelets of PHP patients: evidence that distinct receptor-cyclase coupling proteins mediate stimulation and inhibition of adenylate cyclase. Proc Natl Acad Sci USA 79:4193-4197

22. Kaartinen JM, Hreniuk S, Martin LF, Ranta S, LaNoue KF, Ohisalo JJ 1991 Attenuated adenosine sensitivity and decreased adenosine receptor number in adipocyte plasma membranes in human obesity. Biochem J 279:17-22

\section{Announcement}

The Society for Behavioral Pediatrics will conduct its 12th Annual Scientific Meeting and Workshops on September 22-26, 1994 at the Marriott City Center in Minneapolis, MN. For further information and registration forms, please contact Ms. Noreen Spota at (215) 248-9168. 